\title{
Healthcare products and food supplements in Poland - a comparison
}

\author{
Katarzyna Hys ${ }^{1, *}$ \\ ${ }^{1}$ Opole University of Technology, 45-758 Opole, Poland
}

\begin{abstract}
The analysis of the level of consumption of food supplements by Poles raises increasing controversy. Many communities pay attention to the alarming situation, including, among others, Central Apothecary Council, National Institute of Medicine, Office of Competition and Consumer Protection, National Sanitary Inspectorate or the Supreme Chamber of Control. For the purpose of this paper, the studies were conducted with the use of the desk research technique. There are many factors which affect the increase in food supplement sales in Poland. One of them is the lack of basic client knowledge concerning the differences between healthcare products and food supplements. Clients identify supplements with medicine, which is wrong. Due to the above, the purpose of the paper is to demonstrate the differences between healthcare products and food supplements. As result, a set of criteria will be established, which will be used to conduct a comparative analysis for a healthcare product and food supplement.
\end{abstract}

\section{Introduction}

In sales, both traditional and online, there are many pharmaceuticals with various applications and effects. This paper will focus on the market of food supplements and healthcare products.

In general, as part of the studied product group, the following medications are distinguished: prescription products, OTC medicine, food supplements and cosmetics. These medications constitute separate product groups. However, clients often view them as generic products with the same effect and impact on human heath, which is actually not the case. Unfortunately, clients demonstrate a lack of knowledge on food supplements and healthcare products [1], [2]. They do not see any differences between them and in the case of many product they cannot specify their correct application. Clients wrongly think that the effects of products from the specified groups have medicinal consequences, aimed at improving health or healing of a (self-)diagnosed medical condition [3-7].

Due to the above, this paper will include a comparative analysis, the purpose of which is to clearly determine the differences between food supplements and healthcare products. Cosmetics will be purposefully omitted in this comparison, because they do not constitute the subject of this paper.

\footnotetext{
* Corresponding author: k.hys@po.opole.pl
} 


\section{Methodology}

As part of the defined goal, the paper includes studies conducted with the use of the literature analysis method. The studies concerned the nomenclature used in the scope of the studied product group and features used to describe them.

Then, criteria were established based on literature studies and an in-depth subject literature analysis using the desk research technique. In the latter part of the elaboration, the criteria were used to compare food supplements with healthcare products. In consequence, a catalogue of features was developed along with a detailed description of the studied medications in terms of the differences existing between them.

The studies were conducted in two stages. Each of the stages constituted an execution of a defined research purpose. The research purpose was to demonstrate the differences between food supplements and healthcare products. The purpose will be achieved in several stages: identification of the evaluation criteria of the studied medications, benchmarking of the studied products in terms of the defined criteria as well as elaboration and description of the differences.

\section{Results}

The activities aimed at achieving the research purpose included studies conducted in two stages. The first stage consisted of the identification of the evaluation criteria of food supplements and healthcare products. Then, an analysis was conducted, the results of which were used to evaluate and compare these products based on the defined criteria. These activities were executed as part of the second stage of the research.

\subsection{Definition of evaluation criteria}

The literature analysis in the scope of food supplements and healthcare products allowed for establishing a set of criteria. In order to clearly interpret particular evaluation criteria, they were described in details (Table 1).

Table 1. Identified evaluation criteria.

\begin{tabular}{|c|c|}
\hline Criteria & Description \\
\hline \multicolumn{2}{|r|}{ Basic criteria } \\
\hline product group & $\begin{array}{l}\text { food supplement or healthcare products (including prescription and } \\
\text { OTC) }\end{array}$ \\
\hline product type & product type \\
\hline intended purpose & practical purpose of the given product \\
\hline properties & set of characteristic features for the given group \\
\hline indications & recommendations or instructions for use \\
\hline effect & consequence, result of use \\
\hline
\end{tabular}


Table 1. Identified evaluation criteria cont.

\begin{tabular}{|c|c|}
\hline Criteria & Description \\
\hline \multicolumn{2}{|r|}{ Safety criteria } \\
\hline $\begin{array}{l}\text { safety of use - } \\
\text { supervision over } \\
\text { production and use }\end{array}$ & $\begin{array}{l}\text { set of regulations governing the safe conditions of producing the } \\
\text { product, ensuring safety of its consumption }\end{array}$ \\
\hline dosage & standardised and strictly measured portion/dose \\
\hline information leaflets & contents and substantive content \\
\hline \multicolumn{2}{|r|}{ Criteria concerning product marketing } \\
\hline $\begin{array}{l}\text { legal } \\
\text { regulations/concerning } \\
\text { product registration on } \\
\text { the market }\end{array}$ & $\begin{array}{l}\text { legal regulations concerning the requirements/obligations imposed on } \\
\text { producers to register the product for market sales }\end{array}$ \\
\hline $\begin{array}{l}\text { method of marketing } \\
\text { (sales) }\end{array}$ & current regulations on and procedures of product marketing \\
\hline $\begin{array}{l}\text { documentation required } \\
\text { for product } \\
\text { marketing }\end{array}$ & type of documentation required during product marketing \\
\hline $\begin{array}{l}\text { designation of the } \\
\text { number of permit for } \\
\text { marketing }\end{array}$ & individual number constituting a permit for marketing \\
\hline packaging designation & designation of the product group used on the packaging \\
\hline \multicolumn{2}{|r|}{ Market appeal criteria } \\
\hline availability & product market availability, sales points \\
\hline packaging & originality, imitation \\
\hline
\end{tabular}

Sixteen criteria were identified based on the literature studies. These criteria were classified in four thematic groups. The following criteria were distinguished: basic, concerning consumption safety, product marketing and market appeal.

In the latter part of the paper, the defined criteria will be used to develop a profile of the studied product groups. Then, the profile will be used to provide a description of the differences between food supplements and healthcare products.

\subsection{Food supplements vs. healthcare products - a benchmark}

The characteristic features of food supplements and healthcare products were defined for the designated evaluation criteria (Table 2).

Table 2. Food supplements vs. healthcare products [8].

\begin{tabular}{|c|c|c|}
\hline \multirow{2}{*}{ Criterion } & \multicolumn{2}{|c|}{ Product Group } \\
\cline { 2 - 3 } & Food supplement & $\begin{array}{c}\text { Healthcare products } \\
\text { (including prescription and } \\
\text { OTC) }\end{array}$ \\
\hline \multicolumn{3}{|c|}{ Basic criteria } \\
\hline product type & food product & medical product \\
\hline
\end{tabular}




\begin{tabular}{|c|c|c|}
\hline intended purpose & $\begin{array}{c}\text { diet } \\
\text { supplementation }\end{array}$ & $\begin{array}{c}\text { diagnosis or restoration, } \\
\text { improvement or modification of } \\
\text { the organism's physiological } \\
\text { functions }\end{array}$ \\
\hline properties & $\begin{array}{l}\text { source of vitamins } \\
\text { or mineral nutrients }\end{array}$ & $\begin{array}{l}\text { properties of prevention } \\
\text { or treatment of diseases }\end{array}$ \\
\hline indications & no indications & $\begin{array}{l}\text { specified in the medicinal } \\
\text { product description, detailed in } \\
\text { the leaflet }\end{array}$ \\
\hline effect & $\begin{array}{l}\text { nutritious or other } \\
\text { physiological effect }\end{array}$ & $\begin{array}{l}\text { pharmacological, immunologic } \\
\text { or metabolic }\end{array}$ \\
\hline \multicolumn{3}{|c|}{ Safety criteria } \\
\hline $\begin{array}{l}\text { safety of use - supervision } \\
\text { over production and use }\end{array}$ & $\begin{array}{l}\text { no statutory requirement of } \\
\text { continuous monitoring of } \\
\text { safety of use }\end{array}$ & $\begin{array}{l}\text { continuous supervision } \\
\text { and monitoring of the quality by } \\
\text { the pharmaceutical inspectorate }\end{array}$ \\
\hline dosage & $\begin{array}{c}\text { administration } \\
\text { in small measured unit } \\
\text { quantities } \\
\text { (universal doses) } \\
\end{array}$ & $\begin{array}{l}\text { strictly according to physician's } \\
\text { recommendations }\end{array}$ \\
\hline information leaflets & not subject to approval & $\begin{array}{l}\text { subject to approval } \\
\text { by the URPLWMiPB }\end{array}$ \\
\hline \multicolumn{3}{|c|}{ Criteria concerning product marketing } \\
\hline $\begin{array}{l}\text { legal regulations/concerning } \\
\text { product registration on the } \\
\text { market }\end{array}$ & does not require registration & requires registration \\
\hline method of marketing (sales) & $\begin{array}{l}\text { notification of the Chief } \\
\text { Sanitary Inspectorate } \\
\text { and submission of } \\
\text { packaging design }\end{array}$ & $\begin{array}{c}\text { based on an application } \\
\text { submitted to URPLWMiPB or } \\
\text { EC }\end{array}$ \\
\hline $\begin{array}{l}\text { documentation required } \\
\text { for product } \\
\text { marketing }\end{array}$ & no specific documentation & specific documentation \\
\hline $\begin{array}{l}\text { designation of the number } \\
\text { of permit for marketing }\end{array}$ & no number & $\begin{array}{c}\text { number of permit for marketing } \\
\text { on the packaging }\end{array}$ \\
\hline packaging designation & $\begin{array}{c}\text { phrase: } \\
\text { "food supplement" } \\
\text { always aside the trade name }\end{array}$ & $\begin{array}{c}\text { phrase: } \\
\text { "non-prescribed drug" or } \\
\text { "medicinal product issued } \\
\text { without physician's } \\
\text { recommendations - OTC" }\end{array}$ \\
\hline \multicolumn{3}{|c|}{ Market appeal criteria } \\
\hline availability & unlimited & limited \\
\hline packaging & $\begin{array}{l}\text { mainly copy of the } \\
\text { medicine's packaging }\end{array}$ & prototype \\
\hline
\end{tabular}

\section{Discussion}

Studies were conducted for two product groups: food supplements and healthcare products. The analysis of the feature descriptions of food supplements and healthcare products allowed for defining the differences between them.

The key difference between a food supplement and a healthcare product is the product type. In the case of the supplement, it is a food product, i.e. the same as bakery products, vegetables and fruits, meat, etc. Healthcare products, i.e. prescription medicine or OTC constitute medicinal products. This feature is reflected in the description of each next parameter. 
The purpose of consuming food supplements is only (!) to supplement normal diet. In the case of healthcare products, they are used at the time of occurrence of a medical condition, in order to make a diagnosis or restoration, improvement or modification of the organism's physiological functions. Supplements constitute a source of vitamins or mineral nutrients and the purpose of their consumption is to supplement their quantities in the organism. On the other hand, healthcare products have properties that prevent or treat diseases. Therefore, the purpose of use of the two is completely different. This can also be seen when analysing the indications of the studied medications. In the case of supplements, there are no indications for use, whereas in the case of healthcare products indications are precisely specified in the product characterisation included in the information leaflet. The differences are also apparent in the effects or impact of a human organism. In the case of food supplements, only a nutritious or other physiological effect is achieved. The effects of consuming healthcare products are pharmacological, immunological or metabolic. The described differences between the studied products were classified according to the basic criteria.

As part of the criteria groups concerning safety, the safety of use - supervision over production and use was defined first. In the case of food supplements, there is no statutory requirement of continuous monitoring of the safety of preparation production and use. On the other hand, all healthcare products are subject to rigorous procedures of supervision monitored by the pharmaceutical inspectorate. It is interesting that in the case of food supplements, dosage is universal. Clients consume a constant dose regardless of the organism's demand for given vitamins or mineral nutrients, because no tests are conducted which would determine the organism's demand for them. In the case of healthcare products, doses are determined by the treating physician. It is important to be aware that the contents of supplements' information leaflets are not subject to approval. The contents of are only subject to approval by the URPLWMiPB in the case of healthcare products.

The marketing of food supplements does not require product registration. It is only necessary to notify the Chief Sanitary Inspectorate and deliver a packaging design. No specific documentation is provided and the supplement does not have a number of permit for marketing. On the other hand, in the case of healthcare products, it is necessary to register and approve the products for marketing. These are based on an application submitted to the Office for Registration of Medicinal Products, Medical Products and Biocidal Products (URPLWMiPB) or the European Commission, after presenting specific documentation. On this basis, a healthcare product is assigned a number of permit for marketing. The supplement packaging must always have the phrase "food supplement" aside the trade name. On the other hand, healthcare products must have the phrase "nonprescribed drug" or "medicinal product issued without physician's recommendations OTC" on their packaging.

In the case of food supplements, a client has almost an unlimited access to them. It is possible to purchase them in traditional or online sales points, such as pharmacies, small and medium food stores, supermarkets, petrol stations. The sale of healthcare products is limited mainly to pharmacies and pharmacy points. A food supplement packaging imitative - it is very similar to medicine packaging. The packaging of healthcare products is a prototype.

\section{Conclusion}

The conducted analysis served as a basis for developing a catalogue of features along with a detailed description of the studied medications in terms of the differences existing between them. The research purpose was therefore achieved. The analysis of the studied notions allowed for defining the following conclusions. 
Food supplements and healthcare products constitute various product groups. They differ in terms of product type, intended use, properties, indications for use, effects. Completely different regulations and principles of qualitative safety and marketing also apply to both groups. In the case of food supplements, it is possible to state that the existing entries and requirements are dangerous from the point of view of the client's health and life. They do not take into account the basic standards and principles of safety applicable to healthcare products. Widespread availability and omnipresent promotional activities have blurred the boundaries between supplements and healthcare products in the clients' awareness. In effect, clients stock up on supplements on a mass scale by introducing a socalled self-diagnosis and self-treatment. The carefree behaviour of clients who uncritically purchase and consume mass quantities of supplements affects their state of health. In a long period of time it can also result in a catastrophe related to the loss or permanent damage to health.

Due to the above, it is absolutely necessary to conduct educational activities aimed at informing the clients about the differences between food supplements and healthcare products.

\section{References}

1. H. Bojarowicz, P. Dźwigulska, Hygeia Public Health, 47(4), 427-432 (2012)

2. H. Bojarowicz, P. Dźwigulska, Suplementy diety. Część II. Wybrane składniki suplementów diety oraz ich przeznaczenie, Hygeia Public Health, 47(4), 433-441 (2012)

3. A. Brzozowska, Żywność. Nauka. Technologia. Jakość, 4(29), 16-28 (2001)

4. M. Kozłowska-Wojciechowska, Żyjmy w zdrowiu czyli nowa piramida żywienia (Wydawnictwo Prószyński i S-ka, 2004)

5. M. Jarosz, Suplementy diety a zdrowie (PZWL, Warszawa, 2008)

6. G. Krasnowska, T. Sikora, Żywność. Nauka. Technologia. Jakość, 4(77), 5-23 (2011)

7. K. Hys, Managing business growth in a volatile environment, (ed.) I.V. Raguz, Mechanisms stimulating actions customer - decision maker on the market: marketing mix instruments (Dubrovnik International Economic Meeting, Dubrovnik, 2017)

8. K. Hys, Zarzadzanie. Teoria i Praktyka Management, Impact of advertising on the sale of medicinal products and food supplements in Poland (Theory\&Practice, 2017) 